\title{
An important case of misdiagnosis: keloid scar or high-grade soft-tissue sarcoma?
}

\author{
Rebecca Spenser Nicholas, ${ }^{1}$ Matthew Stodell ${ }^{2}$
}

${ }^{1}$ London School of Surgery, London, UK

${ }^{2}$ Plastic \& Reconstructive Surgery, Barts Health NHS Trust, London, UK

\section{Correspondence to} Rebecca Spenser Nicholas, rebeccanicholas@ymail.com

Accepted 14 May 2014
To cite: Nicholas RS Stodell M. BMJ Case Rep Published online: [please include Day Month Year] doi:10.1136/bcr-2014 203600

\section{DESCRIPTION}

Figures 1-3 show a lesion on the anterior chest of a 49-year-old woman which was originally misdiagnosed as a keloid scar.

Keloids are benign, raised, irregular clusters of scar tissue which grow beyond the margins of an original wound due to abnormal proliferation of fibroblasts. They are generally discrepant in colour to that of the surrounding skin and cause pain, itching and significant disfigurement. When keloids become infected they may ulcerate. The chest is a common location and keloid's are often refractory to treatment. ${ }^{1}$ All these features are present in the case photographed. However, as the natural history of the lesion progressed, some of its atypical features became increasingly apparent.

Although keloids can occur in any skin type, they occur more commonly in darker pigmented skin, unlike our patient's. Other atypical features include the lesion's sheer size and degree of projection from the anterior chest wall, and the area of necrosis which appeared at its inferior pole. These features appeared later on in the disease progression, as the lesion began to enlarge more rapidly, outgrowing the blood supply; tell-tale signs that this is a malignant lesion.

The lesion is in fact a rare high-grade soft-tissue sarcoma, fibrosarcomatous dermatofibrosarcoma protuberans (FS-DFSP). DFSP is a soft-tissue sarcoma, a malignant mesenchymal tumour, which typically arises from the dermis of the torso and proximal limbs. The incidence is $3-5$ per million per year. Risk factors remain unclear; however, DFSP is strongly associated with a rearrangement of chromosomes 17 and 22 . Treatment is usually by wide local excision, which gives a high cure rate. FS change occurs in $5-15 \%$ of DFSP cases. FS-DFSP has a significantly more aggressive clinical course with a higher risk of distant metastasis and an inferior prognosis. ${ }^{2}$

\section{Case history}

The patient was a well-kempt Caucasian female with no comorbidities or history of previous trauma or scar in the same region. The lesion initially appeared as a 'tiny red pimple' in the centre of her chest, which had been present for some time before it began to slowly enlarge over a 2-year period.

In 2010, following assessment by a dermatologist and reassurance that the lesion looked benign, she was referred to a plastic surgery unit. The lesion, now $10 \mathrm{~mm}$ diameter, was diagnosed as a keloid scar by a senior clinician. Treatment was started with intralesional steroid injections and silicone gel. However, the lesion continued to grow.
In 2012, she requested a second opinion and was referred to another plastic surgery unit for assessment. By this stage the lesion had reached $65 \times 65 \times 43 \mathrm{~mm}$-approximately the size of a tennis ball (figures 1-3). Excision biopsy was performed and revealed FS-DFSP infiltrating the dermis and subcutis. Staging CT found no distant metastases.

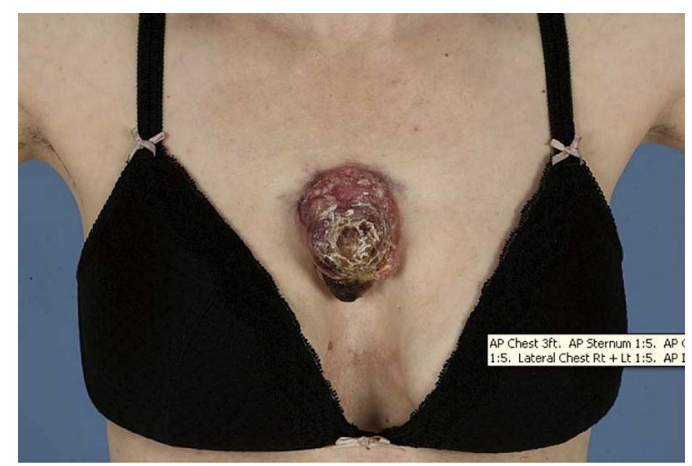

Figure 1 Lesion on anterior chest wall, viewed from front.

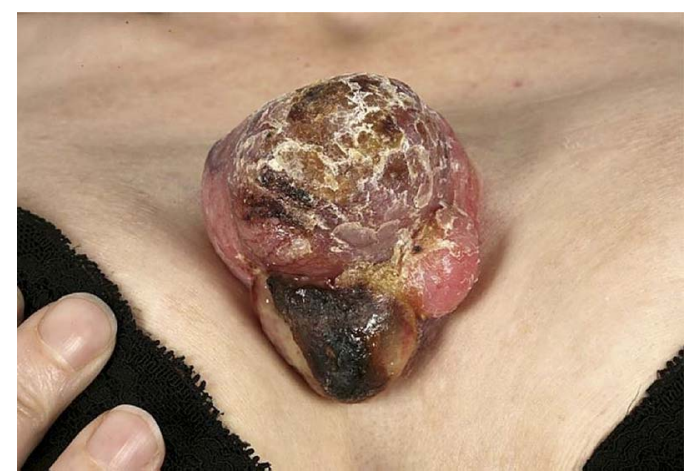

Figure 2 Lesion on anterior chest wall, viewed from below.

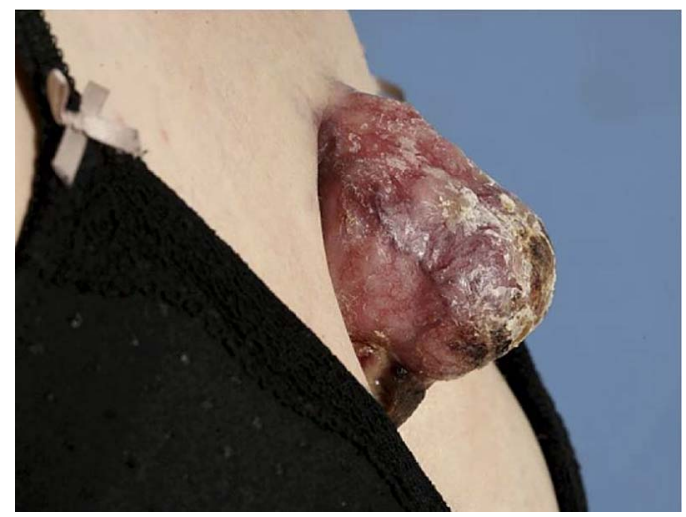

Figure 3 Lesion on anterior chest wall, viewed from the right hand side. 


\section{Learning points}

- This case highlights the importance of always considering the full differential diagnosis and taking time to step back and re-assess, especially when a condition fails to respond to treatment.

- Soft-tissue sarcoma should be considered as a differential diagnosis in the case of any soft-tissue lump with atypical features, if enlarging to $>50 \mathrm{~mm}$ diameter or failing to respond to treatment. Appropriate investigation includes imaging and core biopsy to achieve a correct tissue diagnosis. ${ }^{3}$

- Any case of sarcoma should be promptly referred to a specialist sarcoma centre, where patients can receive appropriate management within a multidisciplinary setting. ${ }^{3}$
Acknowledgements The authors acknowledge Professor Simon Myers Centre for Cutaneous Research, Blizard Institute, Barts and The London School of Medicine and Dentistry, London.

Competing interests None.

Patient consent Obtained.

Provenance and peer review Not commissioned; externally peer reviewed.

\section{REFERENCES}

1 Chike-Obi CJ, Cole PD, Brissett AE. Keloids: pathogenesis, clinical features, and management. Semin Plast Surg 2009;23:178-84.

2 Stacchiotti S, Pedeutour F, Negri T, et al. Dermatofibrosarcoma protuberans-derived fibrosarcoma: clinical history, biological profile and sensitivity to imatinib. Int I Cancer 2011;129:1761-72.

3 Clark MA, Fisher C, Judson I, et al. Soft-tissue sarcomas in adults. N Engl I Med 2005:353:701-11.

Copyright 2014 BMJ Publishing Group. All rights reserved. For permission to reuse any of this content visit http://group.bmj.com/group/rights-licensing/permissions.

BMJ Case Report Fellows may re-use this article for personal use and teaching without any further permission.

Become a Fellow of BMJ Case Reports today and you can:

- Submit as many cases as you like

- Enjoy fast sympathetic peer review and rapid publication of accepted articles

- Access all the published articles

- Re-use any of the published material for personal use and teaching without further permission

For information on Institutional Fellowships contact consortiasales@bmjgroup.com

Visit casereports.bmj.com for more articles like this and to become a Fellow 